logos_i_ethos_2014_1_(36), s. 263-269

Lucyna Skraba

\title{
Polityczne oblicze hermeneutyki
}

\begin{abstract}
Andrzej Przyłębski, Dlaczego Polska jest wartością. Wprowadzenie do hermeneutycznej filozofii polityki, Wydawnictwo Poznańskie, Poznań 2013, ss. 164
\end{abstract}

\begin{abstract}
Najnowsza książka Andrzeja Przyłębskiego pt. Dlaczego Polska jest wartościa. Wprowadzenie do hermeneutycznej filozofii polityki, która pojawiła się w księgarniach

Lucyna Skraba - doktorantka w Katedrze Etyki Wydziału Filozoficznego Uniwersytetu Papieskiego Jana Pawła II w Krakowie. Interesuje się hermeneutyką, etyką, teorią literatury, antropologią kultury.
\end{abstract} w drugiej połowie 2013 roku, jest kolejną propozycją związaną z hermeneutycznym namysłem nad rzeczywistością. Publikacja jest w jakiejś mierze podsumowaniem dotychczasowych badań prowadzonych przez autora (odwołuje się w niej między innymi do swoich wcześniejszych publikacji), ale przede wszystkim przedstawia zarys hermeneutycznej filozofii polityki, koncepcji, która nie była dotychczas na polskim gruncie wprost wyartykułowana. Sam autor sygnalizuje we Wstępie, że jest to kolejna książka - po Hermeneutycznym zwrocie filozofii, monografii Gadamer poświęconej niemieckiemu filozofowi, którego Przyłębski jest uczniem, oraz Etyce ws świetle hermeneutyki - na kartach której myślenie o hermeneutyce jako o systemie filozoficznym jest stale obecne. Filozofię, której istotę od wielu lat zgłębia, rozumie tak:

Wedle mego ujęcia, filozofia hermeneutyczna jest filozoficzną teorią dotyczącą ludzkiego rozumienia rzeczywistości, z którego wynikają postaci czy też sposoby bycia w świecie. Człowiek jest bowiem nie tylko istotą, której byt określa świadomość, ale również, a może nade wszystko, istotą, u której świadomość (rozumienie, 
samorozumienie, projektowanie egzystencji) określa byt. To właśnie czyni go czymś wyjątkowym we wszechświecie. Kategoria rozumienia, bardzo pojemna i na sposób znany z fenomenologii skorelowana ze sposobami odsłaniana się (prezentowania się) rzeczywistości, daje olbrzymie możliwości filozoficznej analizy, stale odniesionej do całości egzystencji, a więc do wszystkich nauk o człowieku i kulturze (s. 8).

Książka, mająca tytuł zapewne dla wielu czytelników zaskakujący i w jakiejś mierze prowokacyjny, składa się z sześciu w pewnym stopniu autonomicznych rozdziałów. Jej lekturze ciągle towarzyszy pytanie: „Dlaczego Polska jest wartością?”, chociaż na karcie tytułowej znaku zapytania nie zobaczymy, mimo że pojawia się tam zaimek przysłówkowy „dlaczego", rozpoczynający zdanie pytające. Czytelnik będzie więc, bardziej lub mniej świadomie, poszukiwał odpowiedzi na to pytanie na kolejnych stronach książki, co może się okazać dla osoby, która rzadko sięga po wymagające teksty, zadaniem bardzo trudnym. Wobec książki można przyjąć różne strategie czytania. Można więc czytać ją, podążając za myślą autora przez kolejne rozdziały, co będzie ciekawym doświadczeniem dla chcących dowiedzieć się czegoś więcej o hermeneutyce lub przebyć drogę, która doprowadziła do sformułowania zarysu hermeneutycznej filozofii polityki. Równie dobrze jednak można lekturę potraktować wybiórczo i skupić się tylko na wybranych, interesujących daną osobę rozdziałach. Taka decyzja będzie wymagała jednakże od czytelnika pewnej orientacji zarówno w historii filozofii, jak i w zakresie przeobrażeń zachodzących we współczesnej myśli filozoficznej i politycznej.

Głównym celem książki, jak wskazuje Przyłębski, jest „refleksja nad tym, jak powinna wyglądać filozofia polityczna uprawiana z pozycji hermeneutycznych" (s. 15), a więc przez pryzmat myśli filozoficznej Wilhelma Diltheya, Martina Heideggera, Hansa-Georga Gadamera oraz Paula Ricoeura, którzy uważani są za klasyków filozofii hermeneutycznej. Filozofowie ci zostają jednocześnie postawieni w opozycji do Jaques'a Derridy, Michela Foucaulta, Gillesa Deleuze’a, a także Richarda Rorty'ego czy Gianniego Vattima, reprezentujących myślenie postmodernistyczne, które nie jest, co zostało dobitnie podkreślone, w swojej 
istocie filozofią hermeneutyczną. Przyjrzyjmy się zatem pobieżnie problematyce podejmowanej w kolejnych częściach książki.

$\mathrm{W}$ pierwszym rozdziale zostaje przypomniane, na czym polegał hermeneutyczny zwrot $\mathrm{w}$ filozofii europejskiej. Wskazane zostają również - co jest niezbędne dla dalszych analiz - podstawowe kategorie filozofii hermeneutycznej. Są nimi: rozumienie, traktowane jako sposób bycia człowieka w rzeczywistości (rozumienie - podkreślmy - które jest zawsze sytuacyjne i perspektywiczne), doświadczenie (indywidulane i zbiorowe) oraz język, traktowany jako miejsce, medium odsłaniania się bytu, który jest zawsze, co niezmiernie istotne, językiem jakiejś wspólnoty i dzięki temu nie tylko umożliwia dialog (rozmowę) z innym człowiekiem i własną kulturą, ale także pozwala zrozumieć odmienne światy kulturowe. W kolejnym rozdziale uwaga skupia się na uzasadnieniu tezy, że: „filozofia hermeneutyczna, rozwijana w duchu Gadamera, Ricoeura, Diltheya i Heideggera [...], nie należy do szerokiego prądu kulturowo-społecznego określanego mianem postmodernizmu lub ponowoczesności” (s. 9), z którym bywa utożsamiana i co - jak dodaje Przyłębski - „zagraża jej wizerunkowi i jej istnieniu” (s. 9). Wyakcentowany zostaje fakt, że często błędnie identyfikuje się współczesnych myślicieli jako tych, którzy zajmują się filozofią hermeneutyczną (np. Derrida), lub chcą być z nią identyfikowani (np. Foucault, Caputo, Vattimo, Rorty), wprowadzając tym samym terminologiczne zamieszanie. Na kolejnych stronach znajdziemy więc dookreślony „rdzeń ideowy” postmodernizmu, a następnie analizę dekonstrukcjonizmu Derridy, która ma pokazać, że myślenie twórcy Grammatologii jest ponowoczesne, podobnie jak radykalna hermeneutyka Johna D. Caputo - ta ostatnia również zostaje poddana krytyce. Wskazanie podstawowych różnic między klasycznie pojmowaną hermeneutyką (w odwołaniu głównie do Gadamera) a jej ponowoczesnymi wersjami sprowadza się między innymi do wyakcentowania, jak w tych koncepcjach ujmowany jest język, jaki jest stosunek do prawdy oraz jakie jest podejście do tradycji. Na uwagę zasługuje również fragment będący obroną Gadamera przed zaliczeniem go do grona filozofów postmodernistycznych, co uczynił Andrzej Bronk w przywołanym artykule Krajobraz postmodernistyczny z 1996 roku, opublikowanym w piśmie „Ethos”. 
Analizy z trzeciego rozdziału skoncentrowane są na pokazaniu, jak wiele hermeneutyka współczesna zawdzięcza klasycznej filozofii niemieckiej, w tym szczególnie Immanuelowi Kantowi i rozumieniu przez niego człowieka i społeczeństwa. Refleksje prowadzone przez autora Krytyki czystego rozumu doprowadziły go do wskazania ustroju republikańskiego jako jedynej racjonalnej drogi, którą powinno podążać państwo. Dalsze poruszone zagadnienia to koncepcja filozofii wolności w ujęciu Johanna G. Fichtego oraz teoria nowoczesnego państwa wypracowana przez Georga W. F. Hegla.

Kategorialne podstawy hermeneutycznego ujęcia polityczności zostają dookreślone w rozdziale czwartym, podzielonym wewnętrznie na trzy części, z których każda poświęcona jest innemu problemowi. I tak kolejno mamy przedstawione interesujące refleksje na temat etyki i moralności, mowy ojczystej oraz tradycji, pojętej jako „ogół form kulturowego współistnienia i współdziałania pochodzących z dawnej wspólnoty językowej” (s. 82).

Pisząc o etyce, Przyłębski podkreśla, że nie chodzi o stworzenie jakiejś nowej etyki normatywnej, lecz o hermeneutyczny namysł nad etyką, który ma nam pomóc w zrozumieniu moralności, będącej - czy tego chcemy czy nie - składnikiem tradycji, duchowego dorobku, „który należy uwzględnić i szanować, do którego nie można jednak podchodzić bezkrytycznie" (s. 87). Ten namysł nad kwestiami etycznymi nie może być jednakże tożsamy z ich destrukcją pod znakiem Nietzschego czy Foucaulta, co nie oznacza, że nie należy z nimi wejść w merytoryczny dialog. Taki dialog, który powinien prowadzić do „efektywnego porozumienia”, należy również podjąć na przykład z etyką religijną, a w ten sposób pokazać jednostce i społeczeństwu, że „warto być moralnym” we współczesnym świecie, naznaczonym różnego rodzaju kryzysami. Autor wskazuje też na jakże istotną rolę edukacji etycznej. Jej celem jest „wytwarzanie w człowieku, który ma osiągnąć pewną dojrzałość i włączyć się produktywnie do danej wspólnoty społecznej, wiedzy na temat etosu tej wspólnoty: jej norm, wartości, ideałów" (s. 91), a która została we współczesnych systemach edukacyjnych prawie całkowicie zmarginalizowana. W charakterystyce narodu, postrzeganego jako wspólnota 
językowa, przypomniane zostają w tej kwestii myśli Heideggera, ale przede wszystkim wypracowane w Prawdzie i metodzie Gadamera refleksje na temat języka, traktowanego jako byt, który może być rozumiany. Takie podejście do języka, z którym utożsamia się autor, ma pokazać, że to dzięki niemu możemy dostrzec całość sensu, doświadczając swoistej partycypacji w dorobku kulturowym minionych pokoleń, czyli - jak chce Gadamer - w „tradycji” lub „przekazie”. To język umożliwia nam poznanie siebie, innych ludzi i świata, ale też predysponuje do stworzenia wspólnoty, która będzie nie tylko funkcjonowała w wymiarze historycznym, ale i nade wszystko kulturowym. Odejście od języka pisanego, „zwrot ikoniczny, prymat pisma obrazkowego, dokonujący się na naszych oczach, głównie w instytucjach publicznych, jest w tym kontekście prawdziwym zagrożeniem - groźbą potwornego zubożenia” (s. 100). Poznanie tradycji (kultury) danego narodu umożliwia więc zrozumienie tego, co w danej społeczności dzieje się dzisiaj. Obcowanie $\mathrm{z}$ dorobkiem kulturowym narodu pozwala nie tylko dostrzec jego ciągłość w wymiarze historycznym (świadomość historyczna) czy kulturowym, ale sytuacja ta zarysowuje ramy tożsamości konkretnej wspólnoty. Dla szczególnej wspólnoty, jaką jest naród, autorytet tradycji ma charakter prymarny i względem niego trzeba zająć aktywne stanowisko.

Intersujący z punktu widzenia zadania, które postawił przed sobą autor, jest rozdział piąty, zatytułowany Hermeneutyczna filozofia polityki. Odwołuje się w nim, co prawda skrótowo, do rozważań w kwestiach społecznych i politycznych podjętych szczególnie przez Diltheya, Gadamera, a także, w końcowej części rozdziału, do Ricoeura i jego koncepcji tzw. małej etyki. Wskazanie kolejno, jaki jest stosunek hermeneutycznej filozofii polityki do ideologii liberalizmu, komunitaryzmu oraz republikanizmu, jest następnym punktem w konstruowaniu zarysu hermeneutycznej filozofii polityki. Konsekwencją tych, dla wielu czytelników zapewne pobieżnych, analiz jest stwierdzenie, że elementy należące do odległych względem siebie doktryn: konserwatyzmu, liberalizmu i demokracji, „łączą się w hermeneutycznej filozofii polityki (a także w większości stanowisk komunitarystycznych) z ideą republikanizmu” (s. 134). A więc, jak konkluduje Przyłębski, „nowoczesne państwo to 
wedle hermeneutycznej filozofii polityki republika” (s. 136). Powyższe rozważania zostały uzupełnione o doprecyzowanie, co znaczą wartości fundamentalne dla hermeneutycznej filozofii polityki takie, jak: patriotyzm, solidarność, równość, prawa człowieka, a więc pojęcia obecne i niejednokrotnie rozmyte we współczesnym dyskursie politycznym, nad którymi nieustający namysł wydaje się konieczny. Na postawione w tytule książki pytanie, dlaczego Polska jest wartością, uzyskujemy odpowiedź w ostatnim rozdziale publikacji, który stanowi pewną rekapitulację wcześniejszych dociekań. Polska jest wartością, ponieważ dzięki niej mamy możliwość bycia „członkami pewnej wspólnoty ducha, wspólnoty moralnej, która swą historią odsłoniła przed światem wartości i ideały godne pielęgnowania" (s. 162). Jednak zdolność dostrzeżenia w ponowoczesnym świecie wartości i ideałów, a idąc dalej - poszukiwanie pewnej wspólnoty ducha, w której odnajdzie się swoje miejsce, wydaje się umiejętnością zbędną, nadmiernie obciążającą współczesnego człowieka.

Książka Przyłębskiego jest, jak wskazuje tytuł, wprowadzeniem do hermeneutycznej filozofii polityki. Hermeneutyka, filozofia hermeneutyczna, jest nie tylko teorią rozumienia, która znajduje zastosowanie przy interpretacji tekstów literackich, ale potraktowana szarzej może stać się czymś o wiele więcej, a próby zastosowania rozstrzygnięć wypracowanych na jej terenie mogą przynieść zaskakujące propozycje rozwiązań w - jak się okazuje - nie tak odległej dziedzinie, którą jest filozofia polityki. Czytelnika może zastanawiać ciągłe odwoływanie się autora do tradycji niemieckiego myślenia i wypracowanego na tym polu sposobu rozumienia świata, jednakże musimy pamiętać, że to w obrębie tej filozofii kształtowały się zręby filozofii hermeneutycznej. Na okładce książki zamieszczona została reprodukcja obrazu Chochoły Stanisława Wyspiańskiego, a praca ta przywołuje nieuchronnie Wesele, dramat interpretowany jako sztuka, w której mamy rozliczenie nie tylko z mitami narodowymi oraz ocenę ówczesnej sytuacji społeczno-politycznej; dramat kończący się chocholim, usypiającym tańcem, który zawiesza jakiekolwiek działanie. Można pokusić się o stwierdzenie, że książka Przyłębskiego jest filozoficznym, ale również niezwykle osobistym 
„rozliczeniem się" z nowymi i starymi mitami narodowymi, uniemożliwiającymi działanie dla wspólnego dobra.

Czytelnicy, którzy poświęcą czas na lekturę, zapewne będą czuli pewien niedosyt i będą oczekiwali na kolejną publikację stanowiącą systematyczną wykładnię hermeneutycznej filozofii polityki. Recenzowana publikacja jest jednak obecnie godną uwagi propozycją, która powinna spotkać się z zainteresowaniem nie tylko filozofów polityki czy politologów i samych polityków, ale wszystkich tych, którym przyszłość narodu leży na sercu. Problemy, na które zwraca uwagę w swojej książce Przyłębski, powinny być poddane pod merytoryczną debatę. Wydaje się to być ważne zwłaszcza teraz, kiedy rywalizujące na scenie politycznej koncepcje nie są już tak do końca atrakcyjne dla przeciętnego, zwykłego obywatela, między inny z uwagi na to, że już dawno przestał się z nimi utożsamiać. Autor swoją książkę „dedykuje wszystkim zagubionym młodym ludziom, którym odwrócenie się od własnej wspólnoty historyczno-kulturowej i zatopienie się w konsumpcji, zabawie, pogoni za modami wydaje się gwarantować nową, "czysto europejską» tożsamość” (s. 11). Publikacja ta powinna stać się pretekstem do poważnej dyskusji na różnych poziomach i w różnych gremiach nad kształtem państwa i rolą w nim jednostki i wspólnoty; dyskusji, w trakcie której pytanie: „Dlaczego Polska jest wartością?” nie spotka się z milczącą odpowiedzią. 